\title{
Endoscopic treatment of a liver hydatid cyst with biliary rupture
}

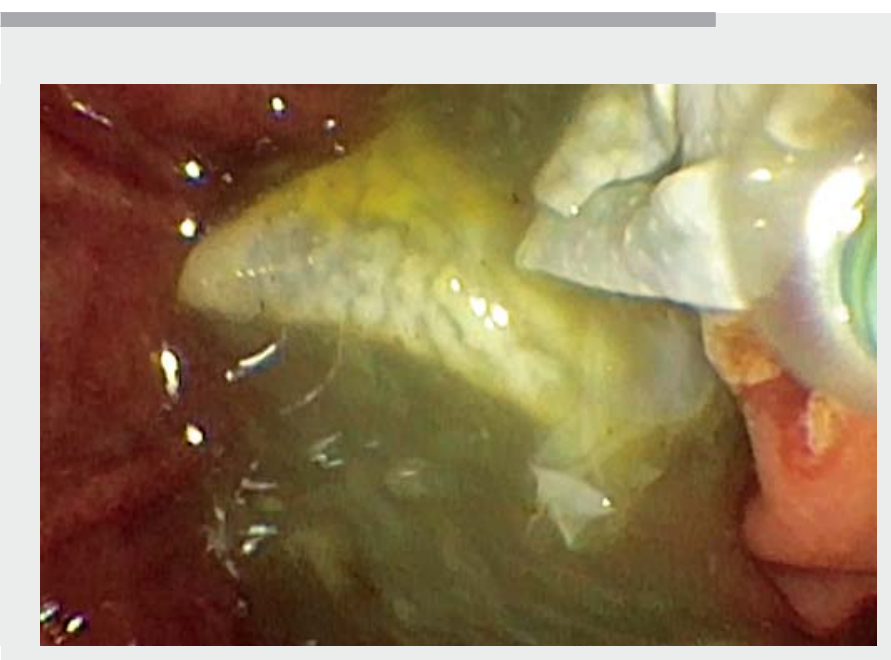

Video 1 Endoscopic retrograde cholangiopancreatography in a 26-year-old man with cholangitis showing the removal of multiple hydatid membranes by balloon sweeps after endoscopic sphincterotomy.

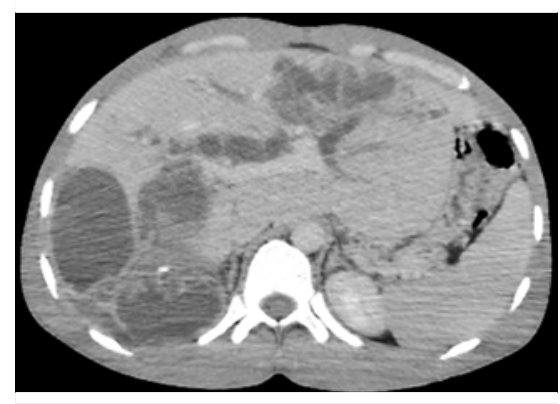

- Fig. 1 Computed tomography scan showing multiple hepatic hydatid cysts with biliary duct dilatation.

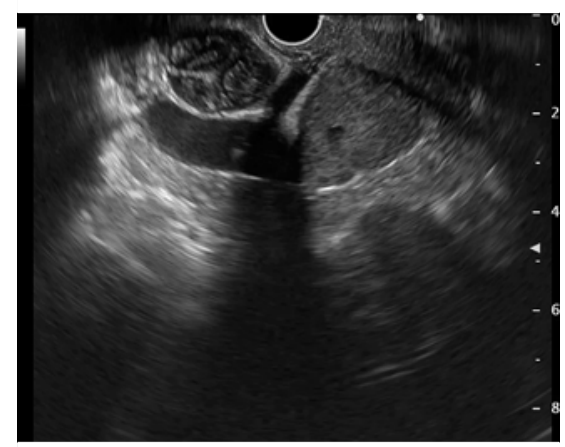

Fig. 2 Linear endoscopic ultrasound view showing multiple echogenic structures within the dilated common bile duct.

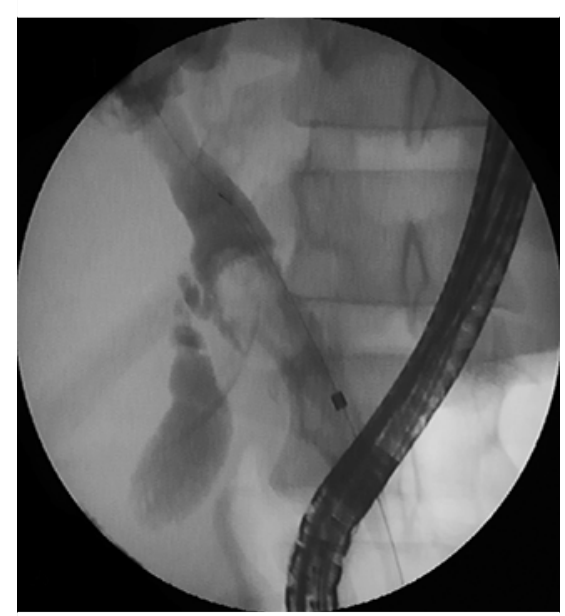

Fig. 3 Fluoroscopic view showing multiple filling defects within the proximal common bile duct.
. Linear endoscopic ultrasound performed before an ERCP showed multiple echogenic structures filling the dila- ted common bile duct (CBD), evocative of hydatid membranes ( $>$ Fig. 2). Urgent ERCP was performed. The fluoroscopic within the enlarged CBD ( $\mathbf{F i g . 3}$ ). Endoscopic sphincterotomy, followed by sweeping of the bile duct with a balloon and basket, allowed removal of multiple hydatid membranes, along with debris and pus, with successful clearance of the biliary tree at the end of the procedure ( $\vee$ Video 1). A plastic stent $(10 \mathrm{Fr} \times 9 \mathrm{~cm})$ was placed to ensure sufficient drainage. The endoscopic treatment resulted in a significant improvement in the patient's clinical and biochemical status, with a normal bile duct diameter at abdominal ultrasonography.

Endoscopy_UCTN_Code_CCL_1AZ_2AN

Competing interests

The authors declare that they have no conflict of interest. 
Mohamed Borahma Yousra Jebari, Fatima

Zahra Chabib, Nawal Lagdali, Imane

Benelbarhdadi, Fatima Zahra Ajana

Department of Gastroenterology C, Mohammed

V University of Rabat, Ibn Sina Hospital, Rabat,

Morocco

Corresponding author

Mohamed Borahma, MD
Mohammed V University of Rabat, Ibn Sina
Hospital, Department of Gastroenterology
C, Rabat, Morocco
borahmamed@gmail.com
m.borahma@um5r.ac.ma

\section{References}

[1] Alghofaily KA, Saeedan MB, Aljohani IM et al. Hepatic hydatid disease complications: review of imaging findings and clinical implications. Abdom Radiol 2017; 42: 199-210

[2] Borahma M, Afifi R, Benelbarhdadi I et al. Endoscopic retrograde cholangiopancreatography in ruptured liver hydatid cyst. Indian J Gastroenterol 2015; 34: 330-334

\section{Bibliography}

Endoscopy 2022; 54: E456-E457

DOI 10.1055/a-1625-4316

ISSN 0013-726X

published online 27.9.2021

(C) 2021. Thieme. All rights reserved.

Georg Thieme Verlag KG, Rüdigerstraße 14, 70469 Stuttgart, Germany

\section{ENDOSCOPY E-VIDEOS}

https://eref.thieme.de/e-videos

口回 Endoscopy E-Videos is an open access online section, 回跣: reporting on interesting cases and new techniques in gastroenterological endoscopy. All papers include a high quality video and all contributions are freely accessible online. Processing charges apply (currently EUR 375), discounts and wavers acc. to HINARI are available.

This section has its own submission website at

https://mc.manuscriptcentral.com/e-videos 